\title{
ZNACZENIE INSTYTUCJI WDÓW W ODNIESIENIU DO STANU DZIEWIC W PIERWSZYCH WIEKACH KOŚCIOŁA
}

O roli kobiet i ich posłudze w pierwotnym Kościele napisano już bardzo wiele $^{1}$. Nie ulega jednak wątpliwości, że i w tym temacie są obszary, które można nadal eksplorować. Wśród różnych kategorii kobiet, będących we wspólnocie kościelnej, niektóre zajmowały specjalne miejsca i sprawowały odpowiedzialne funkcje. Niniejszy artykuł jest próbą przedstawienia instytucji wdów oraz stanu dziewic, ze szczególnym zwróceniem uwagi na ich wzajemne relacje i miejsce w pierwszych wiekach Kościoła.

1. Wdowy. Patrząc chronologicznie, pierwszą kategorię kobiet we wspólnocie chrześcijańskiej, o których mamy świadectwa pisane, stanowią wdowy. Jest to kategoria kobiet, która potrzebowała ochrony. Już w Dziejach Apostolskich spotykamy się z problemem niesienia pomocy wdowom:

„Wówczas, gdy liczba uczniów wzrastała, zaczęli helleniści szemrać przeciwko Hebrajczykom, że przy codziennym rozdawaniu jałmużny zaniedbywano ich wdowy. «Nie jest rzeczą słuszną, abyśmy zaniedbywali słowo Boże, a obsługiwali stoły» - powiedziało Dwunastu, zwoławszy wszystkich uczniów" (Dz 6, 1-2).

${ }^{*}$ Ks. dr Dariusz Zalewski - wykładowca patrologii w Wyższym Seminarium Duchownym w Ełku; e-mail: darekz@tiscali.it.

${ }^{1}$ Wystarczy wymienić przynajmniej niektóre ogólne opracowania, jak J. Daniélou, Le ministre des femmes dans l'Église ancienne, MD 61 (1960) 70-96; R. Gryson, Il ministero della donna nella chiesa antica: un problema attuale nelle sue radici storiche, thum. włoskie A. Bonchino, Roma 1974; P.L. Carle, La femme et les ministères pastoraux d'après la tradition, NV 47 (1972) 263-290; J. Galot, Missione et ministère de la femme, Paris 1973; C. Marucci, La donna e i ministeri nella Bibbia e nella tradizione, RdT 17 (1976) 273-296; M.G. Mara, Le funzioni della dona nella Chiesa antica, „Rivista di Pastorale Liturgica” 19 (1981) fasc. 2, 5-16; E. Schüssler-Fiorenza, In memoria di lei. Una ricostruzione femminista delle origini cristiane, Torino 1990; La donna nel pensiero cristiano antico, a cura di U. Mattioli, Genova 1992; C. Osiek - M.Y. MacDonald, A Woman's Place. House Churches in Earliest Christianity, Minneapolis 2006, czy powstałe na gruncie polskim B. Kulazińska, Rola kobiety w organizacji Kościoła pierwotnego, w: Warszawskie Studia Biblijne, red. J. Frankowski - B. Widła, Warszawa 1976, 343-351; W. Myszor, Rola kobiet w chrześcijaństwie II i III wieku: Wdowy, dziewice i diakonisy, SACh 14 (1999) 12-19. 
O zupełnie innej grupie wdów wydaje się świadczyć kolejny fragment Dziejów Apostolskich, mówiący o przywróceniu przez Piotra do życia uczennicy Tabicie:

„Piotr poszedł z nimi [posłańcami], a gdy przyszedł, zaprowadzili go do izby na górze. Otoczyły go wszystkie wdowy i pokazywały mu ze łzami w oczach chitony i płaszcze, które zrobiła im Gazela za swego życia. Po usunięciu wszystkich, Piotr upadł na kolana i modlił się. Potem zwrócił się do ciała i rzekł: «Tabito, wstań!» A ona otwarła oczy i zobaczywszy Piotra, usiadła. Piotr podał jej rękę i podniósł ją. Zawołał świętych i wdowy i ujrzeli ją żywą" (Dz 9, 39-41).

Podczas gdy pierwszy tekst odnosi się do wdów, które objęte są pomocą charytatywna, drugi z kolei opisuje wdowy jako odrębną grupę, niosącą pomoc braciom. Ze względu na podjęty temat, w niniejszym rozważaniu zajmiemy się tą drugą kategorią wdów.

Z Pierwszego Listu do Tymoteusza dowiadujemy się, że już w pierwotnym Kościele funkcjonowały specjalne listy, na które wpisywano wdowy. Musiały one stanowić znaczną liczbę, skoro autor listu, odwołując się prawdopodobnie do starszych przepisów, podaje sposoby ograniczenia liczby członkiń wyłącznie do tych, „które są rzeczywiście wdowami” $(1 \mathrm{Tm} 5,3)$. Do grona „,rzeczywistych wdów" należy przyjmować tylko tę kobietę,

„[...] która ma co najmniej lat sześćdziesiąt, była żoną jednego męża, ma za sobą świadectwo o [takich] dobrych czynach: że dzieci wychowała, że była gościnna, że obmyła nogi świętych, że zasmuconym przyszła z pomocą, że pilnie brała udział we wszelkim dobrym dziele" (1Tm 5, 9-10).

Ponadto ma ona prowadzić się nienagannie i nieustannie zanosić prośby do Boga (1Tm 5, 5.7).

Z powyższego tekstu trudno jest wywnioskować, czy chodzi w nim o kobiety, które straciły mężów i otrzymywały pomoc od Kościoła, czy też o specjalną instytucję wdów, zaliczaną nawet w poczet kleru². Prawdopodobnie, jak notuje Roger Gryson, w tym fragmencie znajdujemy określenie ideału

${ }^{2}$ Wśród uczonych nie brakuje zwolenników zarówno pierwszej jak i drugiej możliwości. Za pierwszą interpretacją opowiadają się m.in. C.H. Turner, Ministries of Woman in the Primitive Church. Widow, Deaconess and Virgin in the first four Christian Centuries, w: Catholic and Apostolic. Collected Papers, ed. H.N. Bate, London 1931, 319 i J.G. Davies, Deacons, Deaconesses and the Minor Orders in the Patristic Period, JEH 14 (1963) 5. Do tych, którzy dopatrują się już w niniejszym tekście instytucji wdów o charakterze klerykalnym należą F. Wieland, Die genetische Entwicklung der sog: Ordines Minores in nen drei ersten Jahrhunderten, Freiburg 1879, 60; L. Zscharnack, Der Dienst der Frau in den ersten Jahrhunderten der christlichen Kirche, Göttingen 1902, 101; J. Forget, Diaconesses, DThC IV 686; P. Schaefer, Der Dienst der Frau in der Alten Kirche, „Eine heilige Kirche” 21 (1939) 50; Daniélou, Le ministre des femmes dans l'Église ancienne, s. 77; Kulazińska, Rola kobiety w organizacji Kościoła pierwotnego, s. 344-345. 
kobiecego, którego realizacja zaczyna się wraz z małżeństwem, następnie poprzez wdowieństwo przyjmuje formę całkowitego oddania się Bogu w modlitwie, zakładając jednocześnie ślub wstrzemięźliwości. Wspólnota, uznając oficjalnie tę grupę kobiet, pozbawioną jakiegokolwiek wsparcia materialnego, bierze na siebie obowiązek jej utrzymania. Nie ma natomiast żadnej wzmianki o urzędzie sprawowanym przez te wdowy, ani nie ukazują się one jako obdarzone jaką́s specjalną funkcją. Wydają się natomiast w sposób spontaniczny wyrażać swoją wiarę i działalność charytatywną, odgrywając tym samym ważną rolę we wspólnocie ${ }^{3}$.

W okresie poapostolskim słowo ,wdowa” (gr. $\chi \eta ি \rho \alpha)$ bywa niekiedy użyte już jako termin techniczny, określający styl życia, a nie fakt utracenia męża. W Liście do Kościoła w Smyrnie Ignacy z Antiochii, po pozdrowieniu biskupa, kapłanów i diakonów, pozdrawia również „dziewice zwane wdowami”4.

Z II w. pochodzi także inne świadectwo, tak naprawdę jedyne w okresie Ojców Apostolskich, które mówi o oficjalnej misji kobiety we wspólnocie. Otóż w Pasterzu Hermasa spotykamy kobietę imieniem Grapte, która z polecenia staruszki symbolizującej Kościół ma od Hermasa otrzymać jedną z ksiąg objawienia:

„Sporządzisz zatem dwa odpisy małej książeczki i poślesz jeden Klemensowi, a jeden Grapte [...], Grapte zaś będzie pouczała wdowy i sieroty"5.

Prawdopodobnie owa Grapte przynależała do instytucji wdów, a będąc dobrze sytuowana, mogła nieść pomoc innym wdowom i sierotom poprzez katechizację czy wsparcie materialne ${ }^{6}$.

${ }^{3}$ Por. Gryson, Il ministero della donna nella chiesa antica, s. 35-36; A. Covito, L'«ordo viduarum» nella Chiesa antica, w: Se tu conoscessi il dono di Dio. Il carisma della donna nella storia, Noci 1989, 25-28.

${ }^{4}$ Ignatius Antiochenus, Epistula ad Smyrnaeos 13, 1, ed. P.Th. Camelot, SCh 10, Paris 1944, 142, tłum. A. Świderkówna: Ignacy Antiocheński, List do Kościoła w Smyrnie, w: Pierwsi świadkowie, BOK 10, Kraków 2010², 139. Co do znaczenia tego wyrażenia nie ma jednomyślności. Ogólnie przyjmuje się, że chodzi tu o instytucję wdów, w szeregi których przyjmowano również dziewice, por. W.R. Schoedel, Die Briefe des Ignatius von Antiochien, München 1990, 393. Taką interpretację zdaje się potwierdzać świadectwo, jakkolwiek jedyne, Tertuliana, który w swoim dziele $O$ noszeniu zastony przez dziewice notuje: „Plane scio alicubi virginem in viduatu ab annis nondum viginti collocatam" (De virginibus velandis 9, 5, ed. E. Dekkers, CCL 2, Turnholti 1954, 1219). Być może chodzi o inne znaczenie powyższego wyrażenia. Podobnie jak z powodu swojej sytuacji społecznej wdowy były porównywane do sierot, obcych i ubogich (por. Pwt 14, 29; 16, 11 . 14; 24, 19-21; 26, 12-13; Hi 29, 12-13; 31, 16-20; Iz 1, 17), tak ze względu na zachowywaną przez nie czystość przyrównywano je do dziewic, por. Ignatius Antiochenus, Epistula ad Smyrnaeos 13, 1; A. Quacquarelli, w: I Padri Apostolici, thum włoskie A. Quacquarelli, Roma $2005^{10}$, 138, nota 8.

${ }^{5}$ Hermas, Pastor, Visio II 8(4), 3, ed. R. Joly, SCh 53bis, Paris 1997, 96, tłum. A. Świderkówna: Hermas, Pasterz, w: Pierwsi świadkowie, BOK 10, 216.

${ }^{6}$ Por. Daniélou, Le ministre des femmes dans l'Église ancienne, s. 77-78; Osiek - MacDonald, A Woman's Place, s. 113. 
Po raz pierwszy obszerniej na temat wdów we wspólnocie chrześcijańskiej wypowiada się Tertulian. Według niektórych, to właśnie wtedy, na przełomie II i III w., zajmuja one najbardziej eksponowane miejsce w historii istnienia instytucji wdów ${ }^{7}$. Potwierdzenie tego znajdujemy w pismach Tertuliana, gdzie wspomina o tzw. ordo viduarum:

„Jak bardzo powtórne małżeństwo odciaga od wiary, jak bardzo ono sprzeciwia się świętości, ukazuje karność Kościoła i przepis Apostoła, gdy nie zezwala żonatym po raz drugi sprawowania urzędów i gdy nie dopuszcza do stanu wdowiego żadnej innej kobiety jak tylko tę, która była raz zamężną; ona bowiem winna być okazana Kościołowi jako pełna świętości”».

Znajdujemy tutaj potwierdzenie przepisu, znajdującego się już w Pierwszym Liście do Tymoteusza, który dopuszcza do stanu wdowiego jedynie te kobiety, które były tylko raz zamężne.

Kolejne potwierdzenie tegoż wymogu znajdujemy w dziele De virginibus velandis, w którym autor wyraża swoją dezaprobatę wobec przyjęcia w poczet wdów dziewicy niespełna dwudziestoletniej:

„Z całą pewnością poświadczam, że nigdzie nie umieszczono dziewicy w gronie wdów przed dwudziestym rokiem życia. Jeżeli biskup powinien był udzielić jakiejś pomocy takiej [wdowie], to z pewnością przez wzgląd na karność nie zdołałby dokonać tego inaczej, jak tylko w ten sposób, że dziewica-wdowa: taki właśnie dziwolag - nie powiem potwór - nie będzie piętnowana nawet $\mathrm{w}$ Kościele... Lecz jakaś dziewica tam zasiada i jest chroniona taką właśnie powagą. Na to miejsce niegdyś wybierano jedynie raz zamężne, to jest małżonki, mające sześćdziesiąt lat życia".

Z fragmentu tego dowiadujemy się, że podczas eucharystii wdowy zajmowały w kościele specjalne miejsca, otaczając wokoło swojego biskupa ${ }^{10}$.

W dziele De monogamia, napisanym już pod silnym wpływem montanizmu, Kartagińczyk strofuje wdowę, która pragnie ponownie wyjść za mąż:

„Skoro więc zgodnie z nauką Apostoła chcesz «wyjść za mąż w Panu» (jeśli mimo wszystko zależy ci na tym), jaka jesteś, domagając się małżeństwa i to dla tych, którym nie wolno się powtórnie żenić: od biskupa monogamicznego,

\footnotetext{
${ }^{7}$ Por. B.B. Thurston, The Widows: A Women's Ministry in the Early Church, Minneapolis 1989.

${ }^{8}$ Tertullianus, Ad uxorem I 7, 4, ed. E. Kroymann, CCL 1, Turnholti 1954, 381: „Quantum detrahant fidei, quantum obstrepant sanctitati nuptiae secundae, disciplina ecclesiae et praescriptio apostoli declarat, cum digamos non sinit praesidere, cum uiduam adlegi in ordinem nisi uniuiram non concedat. Aram enim dei mundam proponi oportet. Tota illa ecclesiae candida de sanctitate", thum. K. Obrycki: Tertulian, Do żony, w: Tertulian, Wybór pism, II, PSP 29, Warszawa 1983, 154-155.

${ }^{9}$ Tenże, De virginibus velandis 9,5 , CCL 2, 1219, tłum. K. Obrycki: Tertulian, O noszeniu zastony przez dziewice, w: Tertulian, Wybór pism, III, PSP 65, Warszawa 2007, 95.

${ }^{10}$ Tenże, De exhortatione castitatis 11, 2, ed. E. Kroyman, CCL 2, 1031, tłum. K. Obrycki: Tertulian, Zachęta do czystości, w: Tertulian, Wybór pism, II, PSP 29, 177.
} 
od prezbiterów i również diakonów związanych tym sakramentem czy też wdów, których sposób życia odrzucasz"11.

Wdowa pod względem wymagań zrównana jest tu z biskupem, prezbiterami i diakonami.

W jednym z ostatnich pism Tertuliana - De pudicitia wdowy figuruja w grupie osób, które proszone są przez penitentów o wstawiennictwo za nimi:

„A ty wprawdzie, kiedy wprowadzasz do Kościoła pokutę cudzołożnika dla wyproszenia braterstwa, przedstawiasz go ubranego we włosiennicę, posypanego popiołem i przystrojonego zawstydzeniem i trwoga, na środku przed wdowami i starszymi [...]"12.

Pochodząca z 1. poł. III w. Traditio Apostolica wymienia wśród hierarchii kościelnej również wdowy:

„Wdowa zaś, przy swym wprowadzeniu, nie zostaje poświęcona, ale jest wybierana z imienia. Jeżeli jej mąż umarł dawno, niech zostanie wprowadzona. Jeżeli jest stara, niech zostanie poddana próbie przez pewien czas. Często bowiem namiętności zakorzeniają się w tym, kto pozostawił im miejsce w samym sobie. Niech wdowa będzie wprowadzana tylko przez słowo i niech przyłączy się do pozostałych. Nie kładzie się na nią rękę dlatego, że nie przynosi ona ofiary i nie ma urzędu liturgicznego. Święcenia sprawuje się tylko nad klerykami ze względu na ich posługi liturgiczne. Wdowa natomiast jest wprowadzana dla modlitwy, a to jest obowiązek wszystkich"13.

W powyższym tekście wyraźnie jest podane, że wdowy stanowią jakby oddzielną instytucję kościelną, z tym jednak zastrzeżeniem, że nie przynależą do kleru. Podkreślone to zostaje przez fakt nienakładania na nie rąk podczas wprowadzania do grona wdów.

Mniej więcej z tego samego okresu pochodzą Didascalia Apostolorum. Ten wschodniosyryjski dokument zaświadcza, że obok zwykłych wdów, które stanowiły szczególną troskę biskupa i wspólnoty, były i takie, które tworzyły swoiste ordo. W jego skład wchodziły te kobiety, które były tylko raz zamężne i skończyły przynajmniej pięćdziesiąt lat życia ${ }^{14}$. Wdowy młodsze, które chciały

${ }^{11}$ Tenże, De monogamia 11, 1, ed. E. Dekkers, CCL 2, 1244, thum. E. Stanula: Tertulian, O jednożeństwie, w: Tertulian, Wybór pism, III, PSP 65, 73.

${ }_{12}$ Tenże, De pudicitia 13, 7, ed. E. Dekkers, CCL 2, 1304, thum. K. Obrycki: Tertulian, O wstydliwości, w: Tertulian, Wybór pism, III, PSP 65, 221.

${ }^{13}$ Traditio Apostolica 10, ed. B. Botte, SCh 11bis, Paris 1968, 66, thum. H. Paprocki: Hipolita Rzymskiego Tradycja Apostolska, STV 14 (1976) fasc. 1, 155.

${ }^{14}$ Por. Didascalia Apostolorum III 1, 1, ed. F. Funk, Didascalia et Constitutiones Apostolorum, t. 1, Paderborn 1905, 182: „Viduas autem costituite eas, quae non sunt minores quinquaginta annis, ut quodammodo propter aetatem longe absint a suspicione, se futuras esse quorum virorum". W odniesieniu do zaleceń Pierwszego Listu do Tymoteusza wiek kobiet przyjmowanych do stanu wdów zostaje obniżony w Didascalia Apostolorum o dziesięć lat. 
pozostać w stanie bezżennym, miały być otoczone troską ze strony biskupa, by nie być zmuszone do ponownego zamążpójścia ${ }^{15}$. Głównym zadaniem wdów była modlitwa za dobrodziejów i za cały Kościół ${ }^{16}$. Obejmował je natomiast podobnie jak wszystkie kobiety - zakaz nauczania ${ }^{17} \mathrm{i}$ udzielania chrztu ${ }^{18}$.

Godność wdów jest podkreślona w Didascalia Apostolorum poprzez fakt umieszczenia ich obok członków kleru ${ }^{19}$. Nie znaczy to, że automatycznie należały one do kleru, lecz - co bardziej prawdopodobne - miały zarezerwowane w kościele oddzielne miejsce ${ }^{20}$. Razem z sierotami były nazywane „ołtarzem” ${ }^{21}$.

Również tworzący w 1. poł. III w. Orygenes zalicza wdowy do osób cieszących się szacunkiem w Kościele:

„Otóż spośród osób zasługujących na szacunek w Kościele wymieniono wdowę, która obok innych dobrych uczynków «umyła nogi świętych». Za śmieszne uważam ścisłe trzymanie się słów i nieokazywanie w Kościele szacunku kobiecie, która ma wszystkie cechy dobrej wdowy przy tym tylko jej braku, że często za pośrednictwem służby okazywała ludziom życzliwość, jeśli będąc zamożną i posiadając majątek obdarowywała gości albo po prostu ludzi potrzebujących wsparcia"22.

W innym miejscu Orygenes potwierdza przepis mówiący o tym, że powtórne małżeństwo pozbawia możliwości udziału w godnościach kościelnych:

${ }^{15}$ Por. tamże III 2, 1-3, ed. Funk, s. 184.186.

${ }^{16}$ Por. tamże III 5, 2, ed. Funk, s. 188.

${ }^{17}$ Por. tamże III 6, 1-2, ed. Funk, s. 190.

${ }^{18}$ Por. tamże III 9, 1-3, ed. Funk, s. 198-200.

${ }^{19}$ Por. tamże III 11, 4-5, ed. Funk, s. 208: „Procul ergo sint viduae a maleditionibus, quia ad benedicendum constitutae sunt. Itaque neque episcopus nec presbyter nec diaconus nec vidua maledictionem emittat ex ore suo".

${ }^{20}$ Por. Gryson, Il ministero della donna nella chiesa antica, s. 83, nota 38. Niektórzy jak Ch. Methuen (Widows, Bishops and the Struggle for Authority in the „Didascalia Apostolorum”, JEH 46 (1995) 197-213) usiłują udowodnić, że Didascalia Apostolorum są próbą narzucenia struktury episkopalnej w Kościele z jednoczesnym zmniejszeniem roli i funkcji kobiet. Zakładałoby to, że w Syrii i Azji Mniejszej w II-III w. istniały grupy chrześcijan, które przyznawały kobietom wiele przywilejów. Didascalia powstałyby więc, przynajmniej częściowo, jako przeciwstawienie się tym grupom.

${ }^{21}$ Por. Didascalia Apostolorum II 26, 4-8, ed. Funk, s. 104: „[...] episcopus in typum Dei praesidet vobis. Diaconus autem in typum Christi adstat; ergo diligatur a vobis. Diaconessa vero in typum sancti spiritus honoretur a vobis. Vidue et orphani in typum altaris putentur autem a vobis"; tamże III 6, 3, ed. Funk, s. 190; tamże III 10, 7, ed. Funk, s. 204; tamże IV 5, 1, ed. Funk, s. 222; Tertullianus, Ad uxorem I 7, 4, CCL 1, 381; Thurston, The Widows, s. 107-113.

${ }^{22}$ Origenes, Commentarius in Joannem 32, 12 (131), ed. E. Preuschen, GCS 10, Leipzig 1903, 444, 15-23, thum. S. Kalinkowski: Orygenes, Komentarz do Ewangelii wedtug św. Jana, ŹMT 27, Kraków 2003, 523. Por. tenże, De oratione 28, 4, ed. P. Koetschau, GCS 3, Leipzig 1899, 377, 17-21. Wyrażenie „umyła nogi świętych”, zaczerpnięte z 1Tm 5, 10, według Orygenesa należy rozumieć nie w sensie literalnym, lecz anagogicznym, jako nauczanie i to tylko kobiet. Zob. tenże, In Isaiam hom. 6, 3, ed. W.A. Baehrens, GCS 33, Leipzig 1925, 273, 9-19; tenże, Commentarius in Joannem 32, 12 (132-133), GCS 10, 444, 24 - 445, 1. 
„Otóż nie tylko rozpusta, ale i powtórne małżeństwo nie pozwala na pełnienie godności kościelnych: albowiem ani biskup, ani kapłan, ani diakon, ani wdowa nie mogą zawrzeć powtórnego małżeństwa"23.

Inny z Aleksandryjczyków - Klemens, pisze, że w Piśmie Świętym jest wiele przepisów odnoszących się do określonych grup we wspólnocie kościelnej:

„W świętych księgach są też niezliczone wskazania dotyczące wybranych osób, jedne dla kapłanów, inne dla biskupów i diakonów, inne jeszcze dla wdów"24.

Pochodzące z końca IV w. (ok. 380) Constitutiones Apostolorum, tworzące najobszerniejszy zbiór chrześcijańskich przepisów liturgiczno-kanonicznych w starożytności, całą III księgę poświęcają stanowi wdowiemu. Ponieważ księgi I-VI Konstytucji opierają się na Didascalia Apostolorum, interesująca jest różnica dolnej granicy wieku kobiet przyjmowanych do stanu wdowiego, jaka istnieje między tymi dwoma dziełami. Podczas gdy w Didascalia Apostolorum - jak widzieliśmy - wdowy, by móc być przyjęte do stanu wdowiego mają mieć przynajmniej pięćdziesiąt lat, w Constitutiones Apostolorum ten wiek zostaje podwyższony do lat sześćdziesięciu i pokrywa się z zaleceniami 1Tm 5, 9:

„Do (stanu) wdów nie włączajcie tych, które nie ukończyły sześćdziesiątego roku życia, gdyż tylko taki wiek może wam dać pewną gwarancję, że nie wyjdą ponownie za mąż"25.

Jest bardzo prawdopodobne, że w Constitutiones Apostolorum instytucja wdów traci powoli na swoim znaczeniu. Można to zaobserwować chociażby przy wyliczaniu poszczególnych członków, wchodzących w skład hierarchii kościelnej. Gdy w Didascalia Apostolorum, jak to było podane wcześniej, zakaz wypowiadania przekleństw jest nałożony kolejno na biskupa, kapłana, diakona i wdowę, tak w Constitutiones Apostolorum wdowy sąjuż pominięte:

„Ani więc biskup, ani prezbiter, ani diakon, ani ktokolwiek inny z katalogu kapłańskiego niechaj nie plami języka obelgą [...]"26.

Co więcej, wymieniane są one nawet za dziewicami:

„Niechaj troszczy się (biskup) o wszystkich: o duchownych, o dziewice, o wdowy i o ludzi świeckich"27.

${ }^{23}$ Tenże, In Lucam hom. 17, 10, ed. M. Rauer, GCS 49, Leipzig 1959, 110, 3-5, tłum. S. Kalinkowski: Orygenes, Homilie o Ewangelii św. Łukasza, PSP 36, Warszawa 1986, 81.

${ }^{24}$ Clemens Alexandrinus, Paedagogus III 12, 97, 2, ed. O. Stählin, GCS 12, Leipzig 1905, 289, 18-20, thum. M. Szarmach: Klemens Aleksandryjski, Wychowawca, Toruń 2012, 222.

${ }^{25}$ Constitutiones Apostolorum III 1, 1, ŹMT 42 [wyd. grecko-polskie, układ i oprac. A. Baron - H. Pietras, thum. S. Kalinkowski], Kraków 2007 = SCL 2, 80.

${ }^{26}$ Tamże III 15, 5, SCL 2, 92.

${ }^{27}$ Tamże. 
Potwierdzenie tego znajdujemy również przy instytucji diakonis, gdzie jest powiedziane, że:

„Na diakonisę należy wybierać czystą dziewicę albo wdowę po jednym mężu, wierną i godną szacunku"28.

Podobnie jak w Didascalia także i w Constitutiones wszystkim kobietom zabrania się udzielania chrztu ${ }^{29}$ oraz nauczania w kościele ${ }^{30}$.

$\mathrm{O}$ posłudze wdów mowa jest także w pochodzących z 1. poł. IV w. $\mathrm{Ka}$ nonów kościelnych świętych Apostołów. Ten egipski dokument nakazuje, aby w każdej wspólnocie wyznaczone były trzy wdowy. Dwie mają modlić się za tych, którzy poddani są cierpieniu i spełniać funkcje prorockie, a trzecia ma zwłaszcza opiekować się chorymi niewiastami ${ }^{31}$.

Pochodzący z V w. Testamentum Domini nostri Iesu Christi, jak żaden inny dokument chrześcijański, nie przyznaje kobiecie tak wielkiego znaczenia i funkcji w hierarchii kościelnej32. Ten syryjski zbiór przepisów liturgiczno-kanonicznych w rzeczywistości bazuje na wcześniejszej Traditio Apostolica. Przepisy dotyczące wdów zostają tu jednak bardziej rozbudowane i poszerzone. Wraz z członkami kleru tworzą one strukturę hierarchiczną Kościoła, będąc wymieniane zaraz po subdiakonach. Testamentum określa nawet ich liczbę we wspólnocie kościelnej na trzy ${ }^{33}$.

Podczas eucharystii wdowy są obecne w prezbiterium, stojąc po lewej stronie biskupa za prezbiterami, podczas gdy po prawej stronie za prezbiterami miejsce mają diakoni ${ }^{34}$. Komunię świętą przyjmują zaraz po diakonach ${ }^{35}$. Należy zauważyć, że wdowy zajmują wyższą pozycję we wspólnocie niż diakonise.

${ }^{28}$ Tamże VI 17, 4, SCL 2, 155.

${ }^{29}$ Por. tamże III 6, 1, SCL 2, 84.

${ }^{30}$ Por. tamże III 10, 1, SCL 2, 89. W Constitutiones Apostolorum (III 5, 3-4, SCL 2, 83) jest mowa o tym, że wdowy mogą prywatnie nauczać, jednak z zachowaniem wszelkich zasad ostrożności i dogmatów wiary.

${ }^{31}$ Por. Canones Ecclesiastici Sanctorum Apostolorum 21, 1-2, ed. F.X. Funk, w: Doctrina Duodecim Apostolorum: Canones apostolorum ecclesiastici ac reliquae doctrinae de duabus viis expositiones veteres, Tubingae 1887, 66-68.

${ }^{32}$ Por. A. Faivre, Naissance d'une hiérarchie. Les premières étapes du cursus clérical, Paris 1977, 106.

${ }^{33}$ Por. Testamentum Domini nostri Iesu Christi 1, 34, ed. I.E. Rahmani, Moguntiae 1899, 83 : „In ecclesia noti sint duodecim presbiteri, septem diaconi, quatuor hypodiaconi (legendum quatuor lectores) et tres vidue habentes praecedentiam sessionis".

${ }^{34}$ Por. tamże 1, 23, ed. Rahmani, s. 35-37: „Primus in medio consistat episcopus, et post ipsum immediate sistant presbiteri hinc et inde, et post presbyteros, qui sunt in parte sinistra, sequantur proxime viduae, post presbyteros, qui sunt in parte dextera, stent diaconi, et post hos lectores, et post lectores hypodiaconi, et post hypodiaconos diaconissae".

${ }^{35}$ Por. tamże 1, 23, ed. Rahmani, s. 35-37: „,Episcopus] offerat intra velum una cum presbyteris, diaconis, viduis canonicis, hypodiaconis, diaconissis, lectoribus et habentibus charismata". 
Przed przyjęciem do specjalnego grona wdów, kandydatka musi przejść okres próbny, który udowodni jej stałość i wytrwałość we wdowieństwie ${ }^{36}$. Szczególna godność i pozycja wdowy we wspólnocie wypływa również z faktu, że podobnie jak biskup, prezbiter, czy diakon zostaje ona oficjalnie wybrana ze wskazania publicznego ${ }^{37}$.

W odróżnieniu od Traditio Apostolica, gdzie jest powiedziane, że wdowy się wprowadza do grona wdów a nie wyświęca, Testamentum mówi o święceniu, którego dokonuje biskup, wymawiając nad kandydatką stosowną modlitwę wypraszającą dla święconej siłę do wypełniania zadań wypływających $\mathrm{z}$ jej $\operatorname{stanu}^{38}$.

2. Dziewice. Stan życia w dziewictwie istniał od pierwszych wieków chrześcijaństwa. Już Ignacy Antiocheński w Liście do Kościoła w Smyrnie pozdrawia "dziewice zwane wdowami" ${ }^{39}$. Świadczy to prawdopodobnie o tym, że w tym czasie nie było jeszcze oddzielnej, formalnej grupy dziewic, ponieważ w praktykowaniu czystości i bezżeństwie upodabniały się one do istniejącej już i uznanej przez Kościół grupy wdów ${ }^{40}$. Potwierdzałoby to późniejsze świadectwo Tertuliana, mówiącego o przyjęciu do grona wdów dziewicy, która nie ukończyła jeszcze dwudziestu lat ${ }^{41}$. Także Justyn i Atenagoras, kiedy piszą o wielkiej liczbie kobiet i mężczyzn wśród chrześcijan, którzy zachowują dozgonną czystość, nie wspominają nic o oficjalnie zorganizowanym stanie dziewictwa ${ }^{42}$.

Ze środowiska egipskiego pochodzi świadectwo Klemensa Aleksandryjskiego, który również wspomina wielką liczbę mężczyzn i kobiet praktykujących wstrzemięźliwość seksualną:

„Pełen jest więc cały Kościół takich ludzi - którzy przez całe swe życie ćwiczą się w gotowości przyjęcia życiodajnej śmierci wiodącej ich do Chrystusa - i to zarówno obyczajnych mężczyzn jak i kobiet. Wolno jest bowiem każdemu żyjącemu w naszej wspólnocie dążyć do mądrości, nawet bez wykształcenia, czy to będąc barbarzyńcą czy Hellenem, czy niewolnikiem, czy starcem,

\footnotetext{
${ }^{36}$ Por. tamże 1, 40, ed. Rahmani, s. 95.

${ }^{37}$ Por. Faivre, Naissance d'une hiérarchie, s. 108, nota 133.

${ }^{38}$ Por. Testamentum Domini nostri Iesu Christi 1, 41, ed. Rahmani, s. 99.

${ }^{39}$ Ignatius Antiochenus, Epistula ad Smyrnaeos 13, 1, SCh 10, 130, BOK 10, 139.

${ }^{40}$ Niektórzy, jak P.-Th. Camelot (Virgines Christi. La virginité aux premiers siècles de l'Église,
} Paris 1944, 27) czy L. Małunowiczówna (Dziewica, EK IV 604) twierdzą jednak, że już w czasach poapostolskich dziewice tworzyły odrębną grupę we wspólnocie.

${ }^{41}$ Por. Tertullianus, De virginibus velandis 9, 5, CCL 2, 1219. Afrykańczyk wyjaśnia, że w Kościele nie ma specjalnego miejsca dla dziewic: ,[...] nihil virgini ad honorem de loco permissum est" (tamże 9, 6, CCL 2, 1219), por. E. Schulz-Flügel, Commentaire, w: SCh 424, Paris 1997, 264.

${ }^{42}$ Por. Iustinus, Apologia I 15, 6, ed. Ch. Munier, SCh 507, Paris 2006, 168; tamże 29, 1, SCh 507, 206; Athenagoras, Legatio pro christianis 33, 2, ed. B. Pouderon, SCh 379, Paris 1992, 196-198. 
czy dzieckiem, czy kobietą. Dostępna jest bowiem wszystkim ludziom, jeśli ją wybiora, wstrzemię́liwość" ${ }^{43}$.

Wraz ze wzrostem ilości dziewic, które wybierają drogę dozgonnego dziewictwa, pojawiają się pierwsze dzieła im dedykowane. W Syrii i Palestynie powstają dwa pseudoklementyńskie listy Do dziewic, w Azji Mniejszej Uczta, czyli dialog o dziewictwie Metodego z Olimpu, w Afryce $O$ noszeniu zastony przez dziewice Tertuliana czy $O$ sposobie życia dziewic Cypriana.

Tertulian zaświadcza, że w Kościele afrykańskim mężczyźni na równi z kobietami poświęcali się życiu w czystości:

„[...] mężczyźni zaś bądź to bezżenni, bądź to z własnej woli trzebieńcy, po omacku stapaliby za swoim dobrem, nie wnosząc niczego, co by ich uszlachetniło" ${ }^{44}$.

Kartagińczyk pisze, że wielu chrześcijan w swoich postanowieniach wstrzemięźliwości seksualnej dożywało sędziwego wieku:

„Nas od takich wypadków (rozwiązłości) odgrodziła bardzo troskliwie przestrzegana i wierna czystość, i tak jak od wszetecznictwa i wszelkich poza małżeństwem wykroczeń, tak samo od kazirodztwa jesteśmy zabezpieczeni. Niektórzy o wiele ostrożniejsi całą siłę tego obłędu trzymają z dala od siebie przez dziewiczą wstrzemięźliwość: starcy - a jeszcze dzieci”"45.

Współczesny Tertulianowi Minucjusz Feliks pisze, że również w Rzymie wielu chrześcijan żyje w dozgonnej czystości:

„Powaga i czystość naszych rozmów i jeszcze większa czystość cielesna nie pozwalaja, by wesołość tych uczt przeszła w rospasanie. Wielu z nas zachowuje dobrowolnie dozgonne dziewictwo nie nadając temu rozgłosu"46.

We wspomnianej przy okazji wdów Traditio Apostolica jest również krótka wzmianka o dziewicach:

${ }^{43}$ Clemens Alexandrinus, Stromata IV 58, 2-4, ed. O. Stählin, GCS 52 [15], Leipzig 1960, 275, 2-8, thum. J. Niemirska-Pliszczyńska: Klemens Aleksandryjski, Kobierce zapisków filozoficznych dotyczacych prawdziwej wiedzy, I, Warszawa 1994, 330.

${ }^{44}$ Tertullianus, De virginibus velandis 10, 1, CCL 2, 1219, PSP 65, 96. Por. tenże, Apologeticum 40, 15, ed. E. Dekkers, CCL 1, 155: „Nos vero ieiuniis aridi et omni continentia expressi, ab omni uitae fruge dilati, in sacco et cinere uolutantes inuidia caelum tundimus, Deum tangimus et, cum misericordiam extorserimus, Iuppiter honoratur!”; tenże, De resurectione mortuorum 61, 6, ed. J.G.Ph. Borleffs, CCL 2, 1010: „Nos quoque, ut possumus, os <a> cibo excusamus; etiam sexum a congressione subducimus. Quod spadones uoluntarii, quod uirgines Christi maritae, quod steriles utriusque naturae infructuosis genitalibus structi”.

${ }^{45}$ Tenże, Apologeticum 9, 19, CCL 1, 105, thum. J. Sajdak: Tertulian, Apologetyk, POK 20, Poznań 1947, 47.

${ }^{46}$ Minucius Felix, Octavius 31, 5, ed. C. Halm, CSEL 2, Vindobonae 1867, 45, thum. M. Szarmach: Minucjusz Feliks, Oktawiusz, w: Apologie, PSP 44, Warszawa 1988, 66-67. 
„Na dziewicę nie kładzie się ręki, albowiem tylko jej oświadczenie czyni ją taką"47.

Podobnie, jak to miało miejsce w przypadku wdowy, dziewicy się nie wyświęca, więc nie nakłada się na nią ręki. Wydaje się jednak, że w odróżnieniu od wdów, nie było jakiegoś szczególnego, oficjalnego wprowadzenia W stan dziewic ${ }^{48}$.

W III w. dziewice żyją nadal przy swoich rodzinach, prowadząc głębsze życie duchowe, lecz nie są jeszcze nazywane dziewicami konsekrowanymi. Oficjalny ryt konsekracji dziewic ma miejsce dopiero w IV wieku ${ }^{49}$.

3. Wartość wdowieństwa a wartość dziewictwa. Bardzo interesujące jest spojrzenie na kształtowanie się świadomości pisarzy wczesnochrześcijańskich w odniesieniu do znaczenia stanu wdowiego i dziewictwa.

W pierwszych pismach chrześcijańskich właściwie nie mówi się wiele o dziewicach, a jeśli już, to są to uwagi natury czysto informacyjnej. Wypływa to najprawdopodobniej z faktu, że dziewice nie stanowią jeszcze formalnej grupy i nie spełniają konkretnych funkcji w życiu Kościoła, a co za tym idzie, nie są też przedmiotem specjalnego zainteresowania autorów. $\mathrm{O}$ wiele więcej miejsca poświęca się wdowom i w hierarchii kościelnej zajmują one miejsce przed dziewicami.

Przekonanie o wyższości wdowieństwa nad dziewictwem można zaobserwować w sposób szczególny w dziełach Tertuliana. W piśmie Ad uxorem Kartagińczyk pisze:

„O szacunku, jaki Bóg okazuje dla stanu wdowiego, mamy właśnie wypowiedź Bożą, przekazaną nam przez proroka: «Sprawiedliwie obchodźcie się z wdowami i sierotami; przyjdźcie i toczcie ze mną spór» - mówi Pan. Zauważ, że Bóg na równi ze sobą stawia dobroczyńców wdowy. Jak bardzo ceni On wdowę, skoro obrońca jej będzie toczył spór z Panem. Nawet dziewice, jak sądzę, nie zostały tak bardzo obdarowane. Chociaż całkowita ich nienaruszalność i pełna świętość mają obietnicę oglądania z bliska Boga, to jednak stan wdowi jest nieco trudniejszy, ponieważ jest łatwiej nie pożądać tego, czego się nie zna, i wzgardzić tym, czego się nigdy nie pragnęło. Zaszczytniejsza jest taka wstrzemięźliwość, która zna swoje prawo, która wie, co widziała. Można wprawdzie uważać dziewicę za szczęśliwszą, lecz wtedy wdowę za gorliwszą, ponieważ pierwsza zawsze miała dobro, druga zaś

${ }^{47}$ Traditio Apostolica 12, SCh 11bis, 68, thum. Paprocki, s. 155.

48 Także w De virginibus velandis $(9,5$, CCL 2, 1219) Tertuliana nie ma żadnej wzmianki o ewentualnych publicznych ślubach czystości złożonych przez dziewicę, którą umieszczono w gronie wdów.

${ }^{49}$ Por. R. Metz, La consécration des vierges dans l'Église romaine, Paris 1954, 54; H. Leclercq, Vierge, virginità, DACL XV/2 3095. 
odnalazła to, co dla niej jest dobrem; w dziewicy została uwieńczona łaska, natomiast we wdowie cnota" ${ }^{50}$.

Wyższość wdowieństwa nad dziewictwem u Tertuliana polega więc na większym osobistym wysiłku, jaki wdowa, znająca już pożycie małżeńskie, musi włożyć by zachować wstrzemięźliwość. W przypadku dziewicy łatwiej jest nie pragnąć tego, czego się nie zna.

Ponadto w czasach Tertuliana wdowy, obok biskupa, prezbiterów, diakonów i prawdopodobnie lektorów, tworzą we wspólnocie w odróżnieniu od zwykłych wiernych tzw. ordo ecclesiae ${ }^{51}$. W De praescriptione haereticorum Afrykańczyk podaje spis osób, zajmujących określone urzędy i spełniających różne funkcji we wspólnocie kościelnej:

„Jedynie Syn Boży pozostał bez grzechu. Cóż więc w tym dziwnego, że jakiś tam biskup, diakon, wdowa, dziewica, nauczyciel, czy nawet męczennik odpada od reguły wiary?" 52 .

Pomimo, że powyższego spisu nie można traktować jako wyliczania od najważniejszej osoby we wspólnocie do mniej ważnej ${ }^{53}$, to jednak nie można się oprzeć, by dostrzec tu dwie listy. Pierwsza schodząca z „biskupem”, „diakonem" i ,wdową” oraz druga wzrastająca z „dziewicą,, „nauczycielem” i ,męczennikiem". Pierwsza lista wskazywałaby na członków ordo ecclesiae, którzy na zgromadzeniach liturgicznych mają wyznaczone specjalne miejsca, natomiast druga wyliczałaby tych, którzy wchodzą w skład zwykłych wiernych.

Podobne stanowisko do Tertuliana reprezentuje żyjący w tym samym czasie, ale w środowisku aleksandryjskim, Klemens Aleksandryjski. W swoim najobszerniejszym dziele Kobierce notuje:

„Niektórzy cenią nawet więcej wstrzemięźliwość wdowy niż dziewicy, gdyż pierwsza dobrowolnie powstrzymuje się od rozkoszy, której już doświadczyła" ${ }^{4}$.

Trudno jest jednoznacznie powiedzieć, czy „niektórzy” użyte przez Aleksandryjczyka odnosiło się do Tertuliana, czy też innych autorów.

${ }^{50}$ Tertullianus, Ad uxorem I 8, 1-3, CCL 1, 382, PSP 29, 155.

${ }^{51}$ Por. E. Cattaneo, I ministeri nella chiesa antica. Testi patristici dei primi tre secoli, Milano 1997, 474, nota 5 .

${ }^{52}$ Tertullianus, De praescriptione haereticorum 3, 5, ed. R.F. Refoulé, CCL 1, 188: „Soli enim Dei filio seruabatur sine delicto permanere. Quid ergo si episcopus, si diaconus, si uidua, si uirgo, si doctor, si etiam martyr lapsus a regula fuerit? Ideo haereses ueritatem uidebuntur obtinere?", thum. E. Stanula: Tertulian, Preskrypcja przeciw heretykom, w: Tertulian, Wybór pism, PSP 5, Warszawa 1970, 42.

${ }^{53}$ Por. J. Ysebaert, Die Amtsterminologie im Neuen Testament und in der Alten Kirche. Eine lexikographische Untersuchung, Breda 1994, 55.

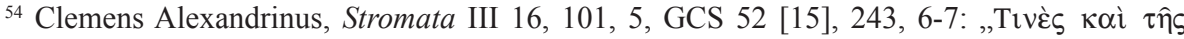

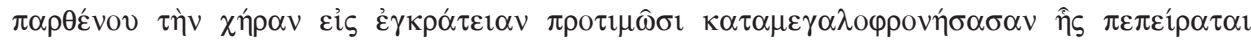

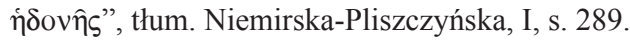


Według Klemensa, wdowa, praktykując cnotę wstrzemięźliwości, odzyskuje ponownie swoje dziewictwo:

„Ten bowiem, kto doznawszy namiętności zapanuje nad nią, podobny jest do wdowy, która poprzez swą wstrzemięźliwość stała się po raz wtóry dziewicą" ${ }^{\prime 5}$.

Także Traditio Apostolica zdaje się stawiać wdowy nad dziewice. Przy omawianiu poszczególnych urzędów i funkcji we wspólnocie, wdowy znajdują się zaraz po prezbiterach, diakonach i wyznawcach, a przed lektorem, dziewicą i subdiakonem ${ }^{56}$.

$\mathrm{Na}$ tym kończą się właściwie świadectwa dające pierwszeństwo wdowie nad dziewicą. Już Orygenes, następny wielki Aleksandryjczyk, tworzący w 1. poł. III w., plasuje dziewice przed wdowami:

„Pierwszym dobrem jest, jeśli kobieta może zachować łaskę dziewictwa. Jeśli zaś nie może, a przydarzy sięjej, że utraci męża, niechaj pozostanie wdową"57.

Pragnąc ukazać różnice wartości między poszczególnymi stanami w Kościele, Orygenes nawiązuje do przypowieści o siewcy i różnych plonów wydanych przez ziemię żyzną:

„[...] gdy zobaczysz w Kościele plony dobrej ziemi «trzydziestokrotne, sześćdziesięciokrotne i stokrotne», to znaczy wdowy, dziewice i męczenników $[\ldots]^{58}$.

Dziewictwo plasuje się więc na poziomie wyższym od wdowieństwa a niższym jedynie od męczeństwa ${ }^{59}$. Tego samego porównania dokonuje Cyprian w De habitu virginum:

„Pierwszy owoc setny jest męczenników, drugi sześćdziesiąty wasz (dziewic) jest. Jak u męczenników nie ma myśli o ciele i świecie, ani małego, lekkiego i przeczulonego obcowania, tak i u was, których drugą jest nagroda łaski, niech będzie i męstwo gotowe do cierpienia" ${ }^{\circ 0}$.

${ }^{55}$ Tamże VII 12, 72, 2, GCS 17, Leipzig 1909, 52, 2-3, tłum. Niemirska-Pliszczyńska, II, s. 275.

${ }^{56}$ Por. Traditio Apostolica 10, SCh 11bis, 66.

${ }^{57}$ Origenes, In Lucam hom. 17, GCS 49, 109, 3-8, PSP 36, 81.

${ }^{58}$ Tenże, In Iosue hom. 2, 1, ed. A. Jaubert, SCh 71, Paris 1960, 119, tłum. S. Kalinkowski: Orygenes, Homilie o Księdze Jozuego, w: Orygenes, Homilie o Księgach Liczb, Jozuego i Sędziów, PSP 34/2, Warszawa 1986, 12.

${ }^{59}$ Por. tenże, Commentatorium in Epistulam ad Romanos 9, 1, PG 14, 1205A: „Et quamvis in Ecclesia prima post apostolos ostia martyrum, seconda virginum videatur".

${ }^{60}$ Cyprianus, De habitu virginum 21, ed. G. Hartel, CSEL 3/1, Vindobonae 1868, 202: „primus cum centeno martyrum fructus est, secundus sexagenarius uester (virginum) est. Ut apud martyres non est carnis et saeculi cogitatio nec parua et leuis et delicata congressio, sic et in uobis, quarum ad gratiam merces secunda est, sit et uirtus ad tolerantiam proxima", thum. J. Czuj: Cyprian, O stroju dziewic, w: Św. Cyprian, Pisma, I, POK 19, Poznań 1937, 152-153. 
Działający w 2. poł. III w. Metody z Olimpu porównując w Simposium wdowy i dziewice ucieka się do wspomnianej wcześniej metafory „ołtarza”:

„Ołtarz powleczony brązem musimy porównać do starców i wdów, bo one są żywym ołtarzem bożym, na którym składamy Panu młode zwierzęta, dziesięciny i dobrowolne ofiary; natomiast ołtarz pozłocony, umieszczony wewnątrz, w najświętszym miejscu, przed obliczem świadectwa, ołtarz, na którym nie wolno składać zwierząt ofiarnych i libacji, należy zestawić z tymi, którzy żyją w dziewictwie: mają one ciała pokryte czystym złotem i nie splamione kontaktami seksualnymi”" ${ }^{\prime 1}$.

Wymienione $\mathrm{w}$ tekście dwa typy ołtarzy wskazują na dwa różne pod względem znaczenia stopnie wewnątrz wspólnoty kościelnej. Metody, opisując w swoim dziele rozwój świadomości moralnej ludzkości, wskazuje na dziewictwo, ołtarz pozłacany, jako stan najdoskonalszy, który jest zwieńczeniem tego rozwoju. Wdowy natomiast porównane są do ołtarza pokrytego brązem, stanowią więc stopień niższy, poprzedzający dziewictwo.

Żyjący w IV w. Bazyli Wielki, pisząc o karach, jakie należy nałożyć na dziewice za popełnione winy, zaznacza:

„Wdowieństwo niżej stoi niż dziewictwo, a zatem grzech popełniony przez

wdowy jest o wiele mniejszy niż grzech popełniony przez dziewice" ${ }^{92}$.

Także Constitutiones Apostolorum wymieniają dziewice przed wdowami i przyznają im pierwszeństwo podczas spotkań liturgicznych:

„[...] dziewice i wdowy niechaj stoją lub siedzą na pierwszych miejscach"63.

Po analizie powyższych świadectw nasuwa się wniosek, że gdzieś od poł. III w. dziewice powoli przejmują pierwszeństwo kosztem stanu wdowiego. Zaczynają one tworzyć odrębną od ogółu wiernych grupę, oddzielny stan w hierarchii kościelnej, zajmujący podczas liturgii miejsce tuż za duchowieństwem. Ich imiona zapisywane są w katalogi lokalnego Kościoła razem z tymi, którzy są uprawnieni do specjalnych modlitw wstawienniczych oraz ewentualnej pomocy materialnej:

„Zapraszała [Helena, matka Konstantyna Wielkiego] także na uczty dziewice, wpisane [na służbę Bogu] do akt kościelnych" ${ }^{64}$.

${ }^{61}$ Methodius Olympius, Symposium, 5, 8, ed. H. Musurillo - V.H. Debidour, SCh 95, Paris 1963, 130-131, thum. S. Kalinkowski: Metody z Olimpu, Uczta, w: Św. Metody z Olimpu, Uczta; Orygenes, Homilie o Pieśni nad Pieśniami, Zachęta do męczeństwa, PSP 24, Warszawa 1980, 62.

${ }^{62}$ Basilius Caesariensis, Epistula 199, 18, PG 32, 717B, tłum. W. Krzyżaniak: Św. Bazyli Wielki, Listy, Warszawa 1972, 204.

${ }^{63}$ Constitutiones Apostolorum II 57, 12, SCL 2, 71. Por. tamże VIII 24-25, SCL 2, 255.

${ }^{64}$ Socrates, HE I 17, PG 67, 121A, tłum. S.J. Kazikowski: Sokrates Scholastyk, Historia Kościoła, Warszawa 1986, 111. Por. Basilius Magnus, Epistula 199, 18, PG 32, 720B; Basilius Ancyranus, De virginitate 61, PG 30, 796C. 
Proces dowartościowania dziewic nasila się wraz z rozwojem klasztorów i życia monastycznego w IV wieku ${ }^{65}$. Coraz częściej opuszczają one swoje rodziny, by podjąć życie we wspólnotach monastycznych.

Jeśli chodzi o urząd wdów, do jego schyłku przyczyniły się dwa historyczne wydarzenia: zmiana statusu ministerialnego w Kościele oraz edykt tolerancyjny Galeriusza z 311 r., przywracający wolność chrześcijaństwu i późniejsza zmiana polityki religijnej w stosunku do chrześcijaństwa w całym Cesarstwie Rzymskim.

W pierwszym przypadku chodzi o stopniową instytucjonalizację Kościoła i nadawanie większego znaczenia hierarchii i urzędom kosztem charyzmatów. Instytucji wdów nie przysłużył się oparty na profetyzmie ruch montanistyczny, w którego szeregach były także prorokujące kobiety. Rzucało to automatycznie podejrzenie na pozostałe kobiety chrześcijańskie, w tym wdowy, ze względu na ich charyzmatyczne formy prowadzenia ${ }^{66}$.

Wraz z edyktem Galeriusza, wiara chrześcijańska staje się religią dozwolona, a z czasem preferowaną. Sprzyja to masowym, acz nie do końca szczerym nawróceniom. Odbija się to na jakości życia religijnego wiernych. Stąd też poszukiwane są nowe formy wyrażania wiary i upodabniania się do Chrystusa. Szeroko pojęta asceza zajmuje miejsce męczeństwa, które do tej pory uznawane było za szczyt chrześcijańskiego heroizmu.

Wydaje się ponadto, że wraz z rozwojem ruchu ascetycznego, który dawał pobożnym kobietom możliwość realizowania duchowych aspiracji, ambicje wdów do odgrywania we wspólnocie aktywnej roli i zajmowania przez nie honorowych miejsc w Kościele z czasem zanikają ${ }^{67}$.

$$
* * *
$$

Podsumowując rozważania na temat wzajemnych relacji między instytucją wdów a stanem dziewic i ich pozycji w pierwszych wiekach Kościoła należy zauważyć, iż relacje te zmieniały się na przestrzeni wieków. Podczas gdy instytucja wdów, powstała $\mathrm{z}$ ustanowienia apostolskiego, tworzy formalne ordo we wspólnocie kościelnej i zajmuje zaszczytne miejsce podczas liturgii, dziewice nie mają oddzielnej grupy, do której mogłyby należeć i często przyjmowane są do grona wdów. Jeszcze Didascalia właściwie nie wspomina nic o dziewicach, natomiast obszernie rozpisuje się o stanie wdowim. Jednak pod koniec III w. sytuacja zaczyna powoli ulegać zmianie. Constitutiones Apostolorum już w sposób wyraźny zajmują się dziewicami i dają im pierwszeństwo przed wdowami.

\footnotetext{
${ }^{65}$ Por. E. Wipszycka, Kościót w świecie późnego antyku, Warszawa 1994, 293.

${ }^{66}$ Por. Thurston, The Widows, s. 115-116.

${ }^{67}$ Por. Wipszycka, Kościót w świecie późnego antyku, s. 293.
} 
Na pewno wymienione $\mathrm{w}$ artykule przyczyny nie wyczerpują wszystkich powodów, dla których w pewnym okresie istnienia Kościoła następuje schyłek instytucji wdów, a dowartościowanie dziewic. Jest jednak faktem, że w IV w. dziewice stanowią już prawdziwe ordo w hierarchii kościelnej, a z czasem tworzą wspólnoty monastyczne, poświęcając się modlitwie i ascezie ${ }^{68}$.

\section{SIGNIFICANCE OF THE INSTITUTION OF WIDOWS IN REFERENCE TO THE STATUS OF VIRGINS DURING THE FIRST CENTURIES OF THE CHURCH}

\section{(Summary)}

Herein the article it is given the analyses of the institution of widows and status of virgins. A special attention is paid to their mutual relations and status at the first centuries of the Church. On the basis of the above mentioned analyses we can see how the mutual relations between them have been changed during centuries. Since the times of the Apostles the widows have been surrounded by a special care and played a very important role at the community. In regard of the great effort which widows, who had been already acquainted with the marital consumption, had to make to keep abstinence their value was greater than value of virgins. A special attention to this fact was paid by Tertullian and Clemens of Alexandria. In the course of time the situation has been slowly changing. The change of the ministerial status at the Church and the edict of toleration issued by Galerius in the year 311 brought to a gradual acceptance by virgins of the status which earlier had been a privilege of widows. The process of valorization was escalating more and more simultaneously with the development of monasteries and monastic life at the IV ${ }^{\text {th }}$ century.

Key words: Church, first centuries, widows, virgins.

Słowa kluczowe: Kościół, pierwsze wieki, wdowy, dziewice.

\section{BIBLIOGRAFIA}

\section{Źródła}

Athenagoras, Legatio pro christianis, ed. B. Pouderon, SCh 379, Paris 1992, 70-208, thum.

S. Kalinkowski: Atenagoras z Aten, Prośba za chrześcijanami, w: Atenagoras z Aten, Prośba za chrześcijanami; O zmartwychwstaniu umarlych, Warszawa 1985, 27-80. Basilius Ancyranus, De virginitate, PG 30, 669-809.

Basilius Caesariensis, Epistula 199, PG 32, 715C - 732C, thum. W. Krzyżaniak: Św. Bazyli Wielki, Listy, Warszawa 1972, 202-213.

\footnotetext{
${ }^{68}$ Por. Metz, La consécration des vierges dans l'Église romaine, s. 59-60.
} 
Canones Ecclesiastici Sanctorum Apostolorum, ed. F.X. Funk, w: Doctrina Duodecim Apostolorum: Canones apostolorum ecclesiastici ac reliquae doctrinae de duabus viis expositiones veteres, Tubingae 1887, 50-73.

Clemens Alexandrinus, Paedagogus, ed. O. Stählin, GCS 12, Leipzig 1905, 87-292, tłum. M. Szarmach: Klemens Aleksandryjski, Wychowawca, Toruń 2012.

Clemens Alexandrinus, Stromata, ed. O. Stählin, I-VI, GCS 15, Berlin 1960; VII-VIII, GCS 17, Leipzig 1909, 3-102, tłum. J. Niemirska-Pliszczyńska: Klemens Aleksandryjski, Kobierce zapisków filozoficznych dotyczacych prawdziwej wiedzy, t. 1-2, Warszawa 1994.

Constitutiones Apostolorum, ŹMT 42 [wyd. grecko-polskie, układ i oprac. A. Baron H. Pietras, tłum. S. Kalinkowski], Kraków 2007 = SCL 2, 1-293.

Cyprianus, De habitu virginum, ed. G. Hartel, CSEL 3/1, Vindobonae 1868, 187-205, tłum. J. Czuj: Św. Cyprian, Pisma, I, POK 19, Poznań 1937, 135-155.

Didascalia Apostolorum, ed. F.X. Funk: Didascalia et Constitutiones Apostolorum, t. 1, Paderborn 1905, 1-384.

Hermas, Pastor, ed. R. Joly, SCh 53bis, Paris 1997, tłum. A. Świderkówna: Hermas, Pasterz, w: Pierwsi świadkowie, BOK 10, Kraków 2010², 211-299.

Ignatius Antiochenus, Epistula ad Smyrnaeos, ed. P.Th. Camelot, SCh 10, Paris 1944, 132-142, tłum. włoskie A. Quacquarelli, w: I Padri Apostolici, Roma 2005², 133-138, tłum. A. Świderkówna: Ignacy Antiocheński, List do Kościoła w Smyrnie, w: Pierwsi świadkowie, BOK 10, Kraków 2010², 136-139.

Iustinus, Apologia I, ed. Ch. Munier, SCh 507, Paris 2006, 126-316, thum. L. Misiarczyk: Św. Justyn, Apologia 1, BOK 24, Kraków 2004, 207-270.

Methodius Olympius, Symposium, ed. H. Musurillo - V.H. Debidour, SCh 95, Paris 1963, tłum. S. Kalinkowski: Metody z Olimpu, Uczta, w: Św. Metody z Olimpu, Uczta; Orygenes, Homilie o Pieśni nad Pieśniami, Zachęta do męczeństwa, PSP 24, Warszawa 1980, 7-14.

Minucius Felix, Octavius, ed. C. Halm, CSEL 2, Vindobonae 1867, 1-71, thum. M. Szarmach: Minucjusz Feliks, Oktawiusz, w: Apologie, PSP 44, Warszawa 1988, 20-77.

Origenes, Commentarius in Joannem, ed. E. Preuschen, GCS 10, Leipzig 1903, thum. S. Kalinkowski: Orygenes, Komentarz do Ewangelii według św. Jana, ŻMT 27, Kraków 2003.

Origenes, Commentatorium in Epistulam ad Romanos, PG 14, 833A - 1292C, thum. S. Kalinkowski: Orygenes, Komentarz do Listu św. Pawła do Rzymian, cz. 1-2, PSP 57, Warszawa 1994.

Origenes, De oratione, ed. P. Koetschau, GCS 3, Leipzig 1899, 295-403, tłum. W. Kania - H. Pietras: Orygenes, O modlitwie, w: Odpowiedź na Słowo. Najstarsi mistrzowie chrześcijańskiej modlitwy, red. H. Pietras, Kraków 1993, 101-240.

Origenes, Homiliae in Iosue, ed. A. Jaubert, SCh 71, Paris 1960, thum. S. Kalinkowski: Orygenes, Homilie o Księdze Jozuego, w: Orygenes, Homilie o Księgach Liczb, Jozuego i Sędziów, PSP 34/2, Warszawa 1986, 3-137.

Origenes, Homiliae in Isaiam, ed. W.A. Baehrens, GCS 33, Leipzig 1925, 242-289, thum. S. Kalinkowski: Orygenes, Homilie o księdze Izajasza, w: Orygenes, Homilie o księgach Izajasza i Ezechiela, ŹMT 16, Kraków 2000, 13-68.

Origenes, Homiliae in Lucam, ed. M. Rauer, GCS 49, Leipzig 1930, tłum. S. Kalinkowski: Orygenes, Homilie o Ewangelii św. Łukasza, PSP 36, Warszawa 1986.

Socrates, HE, PG 67, 33A - 842B, tłum. S.J. Kazikowski: Sokrates Scholastyk, Historia Kościoła, Warszawa 1986. 
Tertullianus, Ad uxorem, ed. E. Kroymann, CCL 1, Turnholti 1954, 371-394, thum. K. Obrycki: Tertulian, Do żony, w: Tertulian, Wybór pism, II, PSP 29, Warszawa 1983, 147-164.

Tertullianus, Apologeticum, ed. E. Dekkers, CCL 1, Turnholti 1954, 77-171, thum. J. Sajdak: Tertulian, Apologetyk, POK 20, Poznań 1947.

Tertullianus, De exhortatione castitatis, ed. E. Kroyman, CCL 2, Turnholti 1954, $1013-$ 1035, tłum. K. Obrycki: Tertulian, Zachęta do czystości, w: Tertulian, Wybór pism, II, PSP 29, Warszawa 1983, 165-181.

Tertullianus, De monogamia, ed. E. Dekkers, CCL 2, Turnholti 1954, 1227-1253, tłum. E. Stanula: Tertulian, O jednożeństwie, w: Tertulian, Wybór pism, III, PSP 65, Warszawa 2007, 59-82.

Tertullianus, De praescriptione haereticorum, ed. R.F. Refoulé, CCL 1, Turnholti 1954, 185-224, thum. E. Stanula: Tertulian, Preskrypcja przeciw heretykom, w: Tertulian, Wybór pism, PSP 5, Warszawa 1970, 40-78.

Tertullianus, De pudicitia, ed. E. Dekkers, CCL 2, Turnholti 1954, 1279-1330, tłum. K. Obrycki: Tertulian, O wstydliwości, w: Tertulian, Wybór pism, III, PSP 65, Warszawa 2007, 199-248.

Tertullianus, De resurectione mortuorum, ed. J.G.Ph. Borleffs, CCL 2, Turnholti 1954, 919-1012.

Tertullianus, De virginibus velandis, ed. E. Dekkers, CCL 2, Turnholti 1954, 1207-1226; ed. E. Schulz-Flügel, SCh 424, Paris 1997, tłum. K. Obrycki: Tertulian, O noszeniu zasłony przez dziewice, w: Tertulian, Wybór pism, III, PSP 65, Warszawa 2007, 85-103.

Testamentum Domini nostri Iesu Christi, ed. I.E. Rahmani, Moguntiae 1899.

Traditio Apostolica, ed. B. Botte, SCh 11bis, Paris 1968, tłum. H. Paprocki: Hipolita Rzymskiego Tradycja Apostolska, STV 14 (1976) fasc. 1, 145-169.

\section{Opracowania}

CAmelot P.Th., Virgines Christi. La virginité aux premiers siècles de l'Église, Paris 1944.

CARle P.L., La femme et les ministères pastoraux d'après la tradition, NV 47 (1972) 263-290.

Cattaneo E., I ministeri nella chiesa antica. Testi patristici dei primi tre secoli, Milano 1997.

Covito A., L' «ordo viduarum» nella Chiesa antica, w: Se tu conoscessi il dono di Dio. Il carisma della donna nella storia, Noci 1989, 25-46.

DAnIÉLOU J., Le ministre des femmes dans l'Église ancienne, MD 61 (1960) 70-96.

Davies J.G., Deacons, Deaconesses and the Minor Orders in the Patristic Period, JEH 14 (1963) 1-15.

Faivre A., Naissance d'une hiérarchie. Les premières étapes du cursus clérical, Paris 1977.

Forget J., Diaconesses, DThC IV 685-703.

Galot J., Missione et ministère de la femme, Paris 1973.

GRYSON R., Il ministero della donna nella chiesa antica: un problema attuale nelle sue radici storiche, tłum. włoskie A. Bonchino, Roma 1974.

Kulazińska B., Rola kobiety w organizacji Kościoła pierwotnego, w: Warszawskie Studia Biblijne, red. J. Frankowski - B. Widła,, Warszawa 1976, 343-351.

La donna nel pensiero cristiano antico, a cura di U. Mattioli, Genova 1992.

LECLERCQ H., Vierge, virginità, DACL XV/2 3094-3108.

MaŁunowiczówna L., Dziewica, EK IV 604-605. 
Mara M.G., Le funzioni della dona nella Chiesa antica, „Rivista di Pastorale Liturgica” 19 (1981) fasc. 2, 5-16.

MARUCCI C., La donna e i ministeri nella Bibbia e nella tradizione, RdT 17 (1976) 273-296.

Methuen Ch., Widows, Bishops and the Struggle for Authority in the „Didascalia Apostolorum", JEH 46 (1995) 197-213.

Metz R., La consécration des vierges dans l'Église romaine, Paris 1954.

Myszor W., Rola kobiet w chrześcijaństwie II i III wieku: Wdowy, dziewice i diakonisy, SACh 14 (1999) 12-19.

Osiek C. - MacDonald M.Y., A Woman's Place. House Churches in Earliest Christianity, Minneapolis 2006.

Schaefer P., Der Dienst der Frau in der Alten Kirche, „Eine heilige Kirche” 21 (1939) 49-57.

Schoedel W.R., Die Briefe des Ignatius von Antiochien, München 1990.

SCHÜSSLER-FIORENZA E., In memoria di lei. Una ricostruzione femminista delle origini cristiane, Torino 1990.

Thurston B.B., The Widows: A Women's Ministry in the Early Church, Minneapolis 1989.

Turner C.H., Ministries of Woman in the Primitive Church. Widow, Deaconess and Virgin in the first four Christian Centuries, w: Catholic and Apostolic. Collected Papers, ed. H.N. Bate, London 1931, 316-351.

Wieland F., Die genetische Entwicklung der sog: Ordines Minores in nen drei ersten Jahrhunderten, Freiburg 1879.

WIPSZYCKa E., Kościół w świecie późnego antyku, Warszawa 1994.

Ysebaert J., Die Amtsterminologie im Neuen Testament und in der Alten Kirche. Eine lexikographische Untersuchung, Breda 1994.

Zscharnack L., Der Dienst der Frau in den ersten Jahrhunderten der christlichen Kirche, Göttingen 1902. 
